\title{
Analysis of Environmental Endocrine Disrupting Activities Using Recombinant Yeast Assay in Wastewater Treatment Plant Effluents
}

\author{
Jian Li $\cdot$ Zijian Wang $\cdot$ Mei Ma $\cdot$ Xianzhi Peng
}

Received: 16 September 2009/Accepted: 8 April 2010/Published online: 21 April 2010

(C) Springer Science+Business Media, LLC 2010

\begin{abstract}
A battery of in vitro recombinant yeast bioassays was conducted to assess the estrogen receptor, androgen receptor, progesterone receptor and thyroid receptor ant/agonistic activities of effluents collected from Datansha wastewater treatment plant (WWTP), furthermore to evaluate the removal efficiencies of endocrine disrupting chemicals in the WWTP. The results showed that estrogenic, anti-androgenic, anti-progesteronic and anti-thyroidic activities were observed in influent. The removal efficiencies of these compounds were more than $80 \%$, which suggested that the present wastewater treatment processes were good enough to remove most of all kinds of endocrine disruption chemicals.
\end{abstract}

Keywords Recombinant yeast assay .

Endocrine disruption chemicals - Wastewater sample

\footnotetext{
J. Li (ه)

College of Water Sciences, Beijing Normal University,

100875 Beijing, People's Republic of China

e-mail: lijian@bnu.edu.cn

Z. Wang $\cdot$ M. Ma

State Key Laboratory of Environmental Aquatic Chemistry, Research Center for Eco-Environmental Sciences, Chinese Academy of Sciences, P.O. Box 2871, 100085 Beijing, China

X. Peng

State Key Laboratory of Organic Geochemistry, Guangzhou Institute of Geochemistry, Chinese Academy of Sciences, 510640 Guangzhou, China
}

\section{Introduction}

Over the past 20 years there has been increasing concern by both the public and researchers that many environmental chemicals, called endocrine disrupting chemicals (EDCs), can modulate the neuro-endocrine system and thus adversely affect human and wildlife reproduction (Colborn et al. 1993). Nuclear receptor (NR) superfamily is a common name for a large group of receptors that are involved in regulation of a wide range of physiological functions in eukaryotic organisms (Janošek et al. 2006). Numerous interactions of EDCs with signaling pathway of NRs were described and several possible mechanisms of action, including direct hormone agonists or antagonists that could mimic or inhibiting endogenous hormone action have been suggested (Sonnenschein and Soto 1998). Thus, NRs have become one of the subjects of research on endocrine disruptors.

It is suggested that industrial and municipal effluents as well as urban and agricultural runoff are the important sources of EDCs discharged into the aquatic environment. In particular, many recent studies have demonstrated that wastewater treatment plant (WWTP) effluents can affect the development of fish embryos and larvae (Tabata et al. 2001) and WWTP effluents are relevant point resources for residues of EDCs in the aquatic environment (Clara et al. 2005). Thus it is necessary to investigate the endocrine disrupting activities in WWTP effluents and to evaluate the detoxication efficiencies of wastewater treatment processes. However, until now, much of the research has focused primarily on estrogen receptor agonists of the WWTP effluents and ignored other potential EDCs target sites (Kristensen et al. 2006). To accurately predict the potential disrupting effects of the WWTP effluents, the interaction of EDCs with other NRs, such as androgen 
receptors, progesterone receptors and thyroid receptors should be studied.

Androgen receptors play an important role in male mammals. Recent studies have demonstrated that several chemicals may exert anti-androgenic effect by interfering with androgen receptor (Sohoni and Sumpter 1998). For example, $p, p^{\prime}$-dichlorodiphenylethane ( $p, p^{\prime}$-DDE), bisphenol A, octylphenol and nonylphenol have demonstrated in vitro androgen receptor-mediated anti-androgenic activities (Xu et al. 2005), some of which are also detected in wastewater with great amount (Sun et al. 2008). Secondly, the effects of progestogen, which is a key regulator of proliferation and differentiation in reproductive tissues (Graham and Clarke 1997), are mediated via the progesterone receptor. Several pieces of evidence indicate that some synthetic chemicals in the environment are able to inhibit the binding of the progesterone to progesterone receptor (Wang et al. 2005). Thirdly, thyroid hormone is essential for normal brain development in both humans and in animals by interaction with thyroid receptor, in addition, increasing evidence from animal and in vitro studies demonstrate that the thyroid is vulnerable to endocrinedisrupting effects (Boas et al. 2006). Industrial chemicals reported to be the major thyroid hormone disruptors include polychlorinated biphenyls (PCBs), dioxins, flameretardants, phenols, and phthalates ( $\mathrm{Li}$ et al. 2008b). Consequently, there is currently a need to validate rapid methods to detect the endocrine disrupting effects of WWTP effluent at the level of all NRs mentioned above.

For this purpose, the recombinant yeast assays were carried out to investigate the effects of effluents in WWTP on estrogen receptor, androgen receptor, progesterone receptor and thyroid receptor-mediated transcription of $\beta$ galactosidase in vitro in reporter yeasts. These test systems could be used for the rapid, high-throughput screening of samples for their agonist and antagonist properties for estrogen receptor, androgen receptor, progesterone receptor and thyroid receptor and assessing the removal efficiencies by the treatment processes in the WWTP.

\section{Materials and Methods}

Wastewater samples were collected in December 2006 from Datansha wastewater treatment plant in Guangzhou, China. The Datansha WWTP, capacity of $165,000 \mathrm{~m}^{3} / \mathrm{d}$, mainly handles residential sewage $(90 \%)$ and serves for 1.5 million populations. This plant was constructed for reclamation of the wastewater consisting of two trains. These trains adopt the identical treatment steps, consisting of grid, sand filter, anaerobic tank, anoxic tank, aerobic tank, clarifier, chlorination. The samples include influent (A), effluent after sand filter treatment (B), effluent from train1 (C), effluent from train2 (D). Grab samples (10 L) were collected and appropriate amount of solvent-cleaned sodium azide $(500 \mathrm{mg} / \mathrm{L})$ was added in each sample right after sampling to suppress possible biotic activities. Samples were stored at $4^{\circ} \mathrm{C}$ and treated within $48 \mathrm{~h}$ according to the modified version of Peng et al. (2008). Water samples (5 L) were extracted by solid phase extraction (SPE) using Oasis C18 cartridges $(6 \mathrm{~mL}$, $1 \mathrm{~g}$, Waters), eluted with the mixture of methanol and acetyl acetate (1:1). Then the raw extracts were filtered by anhydrous sodium sulphate to remove water. This is followed by blowing it to dryness under a nitrogen stream. The residues were dissolved in $0.5 \mathrm{~mL}$ dimethyl sulfoxide (DMSO, Sigma, USA) and diluted by a 0.5 -fold dilution series.

The yeast strains specifically transformed with the estrogen receptor, androgen receptor and thyroid receptor gene were constructed in our laboratory and grown on synthetic dextrose(SD) medium (lacking tryptophan and leucine, SD/-Trp/-Leu) according to description of Li et al. (2008a, b). Another yeast strain transformed with the progesterone receptor gene was a kind gift of Dr. Kevin W. Gaido (Chemical Industry Institute of Toxicology, Research Triangle Park, North Carolina, USA), which was grown in synthetic complete (SC) medium with tryptophane, but lacking histidine and leucine (SC/-His/-Leu) following the prescription of Gaido et al. (1997).

The yeast assay was conducted as described by Ma et al. (2005). In performing the assay, cultures in the exponential growth phase (grown overnight) were diluted with SD/-Leu/Trp or SC/-His/-Leu medium to an $\mathrm{OD}_{600}$ of 0.75. All assays were conducted in at least triplicate. Each triplicate included a positive control and a negative control (DMSO). $5 \mu \mathrm{L}$ of serial dilutions of test samples were combined with $995 \mu \mathrm{L}$ of medium containing $5 \times 10^{3}$ yeast cells $/ \mathrm{mL}$ resulting in a test culture in which the volume of DMSO did not exceed $1.0 \%$ of the total volume. $200 \mu \mathrm{L}$ of the test cultures were transferred into each well of the 96-well plate and incubated at $30^{\circ} \mathrm{C}$ with vigorous orbital shaking $(800 \mathrm{rpm})$ on a titer plate shaker (Heidolph TITRAMAX 1000, Hamburg, Germany) for $2 \mathrm{~h}$, then the cell density of the culture was measured at 600-nm wavelength (TECAN GENios A-5002, Salzburg, Austria). A $50 \mu \mathrm{L}$ test culture was transferred to a new 96-well plate and after addition of $120 \mu \mathrm{L}$ of Z-buffer (16.1 g/L Na $2 \mathrm{HPO}_{4} \cdot 7 \mathrm{H}_{2} \mathrm{O} ; 5.5 \mathrm{~g} / \mathrm{L} \mathrm{NaH} \mathrm{PO}_{4} \cdot \mathrm{H}_{2} \mathrm{O} ; 0.75 \mathrm{~g} /$ $\left.\mathrm{L} \mathrm{KCl} ; 0.246 \mathrm{~g} / \mathrm{L} \mathrm{MgSO}_{4} \cdot 7 \mathrm{H}_{2} \mathrm{O}\right)$ and $20 \mu \mathrm{L}$ chloroform, the assays were carefully mixed (vortex $25 \mathrm{~s}$ ) and preincubated for $5 \mathrm{~min}$ at $30^{\circ} \mathrm{C}$. The enzyme reaction was initiated by addition of $40 \mu \mathrm{L}$ o-nitrophenyl- $\beta$-D-galactopyranoside (13.3 mmol/L, dissolved in Z-buffer). The assays were incubated at $30^{\circ} \mathrm{C}$ on a titer plate shaker. The reactions were terminated by the addition of $100 \mu \mathrm{L} \mathrm{Na}_{2} \mathrm{CO}_{3}(1 \mathrm{~mol} / \mathrm{L})$. For the samples, the incubated time lasted for $60 \mathrm{~min}$. After centrifugation at $12,000 \mathrm{~g}$ for $15 \mathrm{~min}$ (Sigma Laborzentrifugen $2 \mathrm{~K} 15$, Osterode, Germany), $200 \mu \mathrm{L}$ of the supernatant 
was transferred into a new 96 -well plate and the $\mathrm{OD}_{420}$ was determined.

The $\beta$-galactosidase activity was calculated according to the following equations: $u=C s / t \cdot V \cdot D \cdot O D s$ and $C s=10^{-6}$ $\left(A_{S}-A_{B}\right) / \varepsilon \cdot d$ where $u$ : $\beta$-galactosidase activity; $t$ : incubation duration of the enzyme reaction; $V$ : Volume of the test culture; $D$ : dilution factor; $O D_{S}: \mathrm{OD}_{600}$ of test culture; $A_{S}: \mathrm{OD}_{420}$ of the enzyme reaction supernatant of the sample; $A_{B}: \mathrm{OD}_{420}$ of the enzyme reaction supernatant of the blank; $\varepsilon: \varepsilon$ for o-nitrophenol in the enzyme assay reaction mix; and $d$ : diameter of the cuvette (Routledge and Sumpter 1996; Gaido et al. 1997). All samples were evaluated in triplicate and $\beta$-Galactosidase activities of the liquid yeast cultures are expressed as the means and standard deviations. The antagonistic activity of samples was tested by co-incubation of yeast strain with nature ligand as shown in Table 1. The method using ligand in combination with tested chemicals has been widely used to screen the antagonistic activity of estrogen receptor, androgen receptor and progesterone receptor (Wang et al. 2005).

To ensure that increased/reduced activities in the bioassay were caused by true agonistic/antagonistic responses and not by cytotoxicity, viability was measured in cells exposed to samples at the maximum assay concentration. Yeast cells were plated as in the original assay, and then exposed for $2 \mathrm{~h}$ to exposure medium (cell-specific medium containing samples). And cell viability was determined spectrophotometrically as a change of cell density $\left(\mathrm{OD}_{600}\right)$ in the assay medium. In all the bioassays, the procedural blank, which had been subjected to SPE, was also run alongside the samples to monitor for a false-positive result.
In order to evaluate the effects of samples, the toxicity equivalent method was used. For example, the estradiol equivalents (EEQ) values were calculated as described by $\mathrm{Wu}$ et al. (2002) to evaluate the effects on estrogen receptor comparing the estrogenic activity of the sample extracts with the series concentrations of $E_{2}$ standard. Other equivalents were also calculated to evaluate the effects of samples on androgen receptor, progesterone receptor and thyroid receptor (Table 2).

\section{Results and Discussion}

Estrogen receptor agonistic activities were detected in all water samples (Fig. 1). The concentration of EEQ ranged from 1.0 to $10.1 \mathrm{ng} \mathrm{E}_{2}$ equivalents/L (Table 2). In the effluents, the EEQ were no more than $2.5 \mathrm{ng} \mathrm{E}_{2}$ equivalents/L, which were similar to those reported by Cargouët et al. (2004) and Svenson et al. (2003). This WWTP could eliminate more than $80 \%$ of the total effect produced by estrogenic compounds. Many chemical existed in the waste water had been reported to have estrogenic activity. For example, the effluents from WWTPs have been shown to contain $17 \beta$-estradiol, estrone, and some synthetic chemicals, such as $17 \alpha$-ethinylestradiol, nonylphenols, phthalic esters, and phytoestrogens that are able to mimic endogenous estrogen (Ma et al. 2005; Fawell et al. 2001).

To study androgen receptor agonistic activity, androgen receptor yeast was tested in the presence of increasing concentrations of samples. None of the test samples caused any androgen receptor transactivation (Table 2), however,

Table 1 Overview of the four in vitro bioassays used to determine the possible endocrine disrupting potency on 7 different endpoints

\begin{tabular}{|c|c|c|c|c|}
\hline $\begin{array}{l}\text { Endocrine } \\
\text { pathway }\end{array}$ & Bioassay & Reference material & Endpoint & REC50 or RIC50 \\
\hline Estrogenic & $\begin{array}{l}\text { Two-hybrid estrogen } \\
\text { receptor-Laz }\end{array}$ & $\mathrm{E}_{2}$ & Estrogenic activity through estrogen receptor & $2.5 \times 10^{-10} \mathrm{~mol} / \mathrm{L}^{\mathrm{a}}$ \\
\hline \multirow[t]{2}{*}{ Androgenic } & \multirow[t]{2}{*}{$\begin{array}{l}\text { Two-hybrid androgen } \\
\text { receptor-Laz }\end{array}$} & Dihydrotestosteron & $\begin{array}{l}\text { Androgenic activity through androgen } \\
\text { receptor }\end{array}$ & $1.3 \times 10^{-8} \mathrm{~mol} / \mathrm{L}^{\mathrm{a}}$ \\
\hline & & Flutamide & $\begin{array}{l}\text { Anti-androgenic activity through androgen } \\
\text { receptor in the presence of dihydrotestosteron }\end{array}$ & $9.8 \times 10^{-6} \mathrm{~mol} / \mathrm{L}^{\mathrm{a}}$ \\
\hline \multirow[t]{2}{*}{ Progestagenic } & \multirow[t]{2}{*}{$\begin{array}{l}\text { Progesterone } \\
\text { receptor-Laz }\end{array}$} & Progesterone & $\begin{array}{l}\text { Progestagenic activity through progesterone } \\
\text { receptor }\end{array}$ & $5 \times 10^{-10} \mathrm{~mol} / \mathrm{L}^{\mathrm{a}}$ \\
\hline & & RU486 & $\begin{array}{l}\text { Anti-progestagenic activity through progesterone } \\
\text { receptor in the presence of progesterone }\end{array}$ & $6.6 \times 10^{-6} \mathrm{~mol} / \mathrm{L}^{\mathrm{a}}$ \\
\hline \multirow[t]{2}{*}{ Thyroidal } & \multirow[t]{2}{*}{$\begin{array}{l}\text { Two-hybrid thyroid } \\
\text { receptor-Laz }\end{array}$} & $\mathrm{T}_{3}$ & $\begin{array}{l}\text { Thyroid hormone-mimicking ( } \mathrm{T}_{3} \text { like) activity } \\
\text { through thyroid receptor }\end{array}$ & $1.1 \times 10^{-7} \mathrm{~mol} / \mathrm{L}^{\mathrm{b}}$ \\
\hline & & $\begin{array}{l}\text { Amiodarone } \\
\text { hydrochloride }\end{array}$ & $\begin{array}{l}\text { Anti-thyroidic activity through thyroid receptor } \\
\text { in the presence of } T_{3}\end{array}$ & $2.4 \times 10^{-7} \mathrm{~mol} / \mathrm{L}^{\mathrm{b}}$ \\
\hline
\end{tabular}

$\mathrm{E}_{2}, 17 \beta$-Estradiol; OHT, 4-hydroxytamoxifen; $\mathrm{T}_{3}, 3,3^{\prime}, 5$-triiodo-L-thyronine; REC50, the concentration inducing 50\% of the maximum effect; RIC50, the concentration causing a $50 \%$ inhibition of the maximum effect

a According to Li et al. (2008a)

b According to Li et al. (2008b) 
Table 2 Endocrine disrupting potency of effluents collected from Datansha waste water treatment plant tested by a battery of in vitro bioassays

\begin{tabular}{|c|c|c|c|c|c|c|c|}
\hline \multirow{3}{*}{$\begin{array}{l}\text { Water } \\
\text { sample }\end{array}$} & \multicolumn{7}{|c|}{ In vitro potency } \\
\hline & $\begin{array}{l}\text { Estrogen } \\
\text { receptor } \\
\text { agonists }\end{array}$ & $\begin{array}{l}\text { Androgen receptor } \\
\text { agonists }\end{array}$ & $\begin{array}{l}\text { Androgen } \\
\text { receptor } \\
\text { antagonists }\end{array}$ & $\begin{array}{l}\text { Progesterone } \\
\text { receptor agonists }\end{array}$ & $\begin{array}{l}\text { Progesterone } \\
\text { receptor antagonists }\end{array}$ & $\begin{array}{l}\text { Thyroid } \\
\text { receptor } \\
\text { agonists }\end{array}$ & $\begin{array}{l}\text { Thyroid receptor } \\
\text { antagonists }\end{array}$ \\
\hline & $\mathrm{g} \mathrm{E}_{2} / \mathrm{L}$ & $\mathrm{g}$ dihydrotestosteron/L & g flutamide/L & g progesterone/L & g RU486/L & g T3/L & $\begin{array}{l}\text { g amiodarone } \\
\text { hydrochloride/L }\end{array}$ \\
\hline A & $1.01 \mathrm{E}-08$ & ND & $3.40 \mathrm{E}-05$ & ND & $2.60 \mathrm{E}-04$ & ND & $1.70 \mathrm{E}-04$ \\
\hline $\mathrm{B}$ & $3.00 \mathrm{E}-09$ & ND & $3.30 \mathrm{E}-05$ & ND & $1.90 \mathrm{E}-05$ & ND & 4.60E-05 \\
\hline $\mathrm{C}$ & 2.50E-09 & ND & $1.10 \mathrm{E}-07$ & ND & 2.90E-06 & ND & ND \\
\hline $\mathrm{D}$ & $1.00 \mathrm{E}-09$ & ND & ND & ND & $2.30 \mathrm{E}-06$ & ND & ND \\
\hline
\end{tabular}

$A$ extract of influent, $B$ extract of effluent after sand filter treatment, $C$ extract of effluent from train1, $D$ extract of effluent from train2, $E_{2} 17 \beta$ Estradiol, $O H T$ 4-hydroxytamoxifen, $T_{3}$ 3,3',5-triiodo-L-thyronine, $N D$ not detection

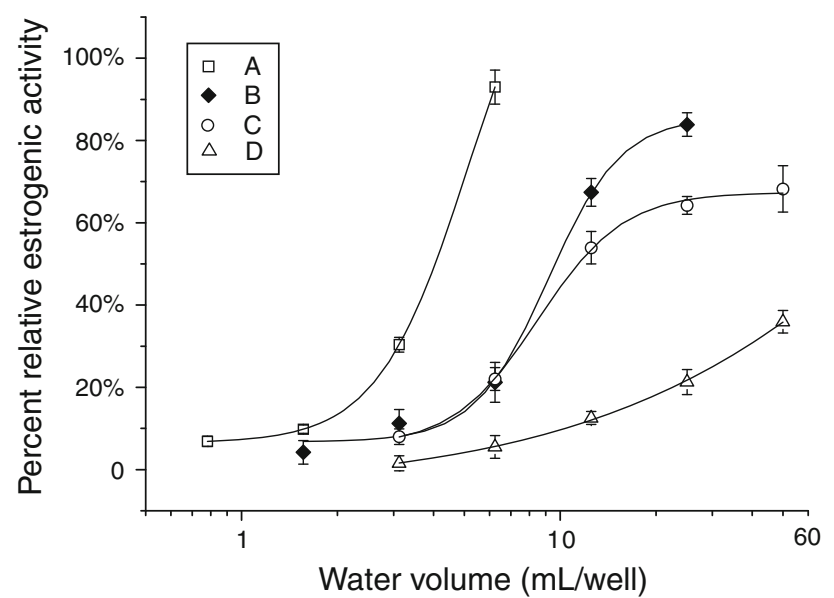

Fig. 1 Estrogen receptor agonistic activities of water extracts determined by the estrogen receptor yeast bioassay. The samples were collected from Datansha waste water treatment plant and the sample's agonistic activity is represented as the percent induction activity relative to the maximum induced by $17 \beta$-Estradiol $\left(\mathrm{E}_{2}, 5 \times 10^{-10}\right.$ $\mathrm{mol} / \mathrm{L})$. Values are presented as the average \pm standard error $(\mathrm{n}=3)$. $A$ extract of influent, $B$ extract of effluent after sand filter treatment, $C$ extract of effluent from train1, $D$ extract of effluent from train2

all samples except the sample D, were found androgen receptor antagonistic activities and the dose-response curves were also obtained (Fig. 2). So, the flutamide equivalent concentrations can be calculated ranging from $1.1 \times 10^{-7}$ to $3.4 \times 10^{-5} \mathrm{~g}$ flutamide equivalents/L (Table 2). The variations of flutamide equivalent concentrations in different treatment processes could be observed clearly, suggesting that these processes eliminated more than $99 \%$ effect. All of the results indicated the high efficiency of the present treatment processes to remove antiandrogenic chemicals. The flutamide equivalent of sample $\mathrm{B}$ was as high as $3.3 \times 10^{-5} \mathrm{~g}$ flutamide equivalents/L, suggesting the sand filter treatment could not effectively remove the anti-androgens. The flutamide equivalents of sample $\mathrm{C}$ and $\mathrm{D}$ decreased greatly, showing that the

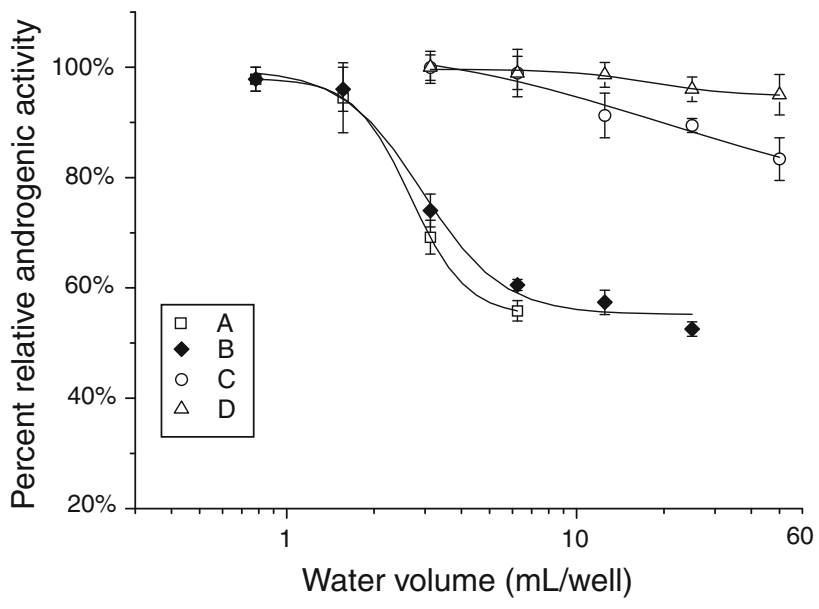

Fig. 2 Androgen receptor antagonistic activities of water extracts determined by the androgen receptor yeast bioassay. The samples were collected from Datansha waste water treatment plant and the sample's antagonistic activity is represented as the percent induction activity relative to the maximum induced by dihydrotestosterone $\left(5 \times 10^{-8} \mathrm{~mol} / \mathrm{L}\right)$. Values are presented as the average \pm standard error $(\mathrm{n}=3)$. $A$ extract of influent, $B$ extract of effluent after sand filter treatment, $C$ extract of effluent from train $1, D$ extract of effluent from train2

combination of biological treatment (an/aerobic tank), clarifier and chlorination were good enough to remove antiandrogens.

In the present study, we found that the occurrence of androgen receptor antagonists, not agonists, in waste water effluents. There were few reports on androgen receptor antagonists in the waste water samples. Tollefsen et al. (2007) firstly reported that androgen receptor antagonists were detected at concentrations of between 20 and $8,000 \mu \mathrm{g}$ of flutamide equivalents/L in effluents from Norwegian North Sea oil production platforms, which were higher than the concentrations we have determined in effluent water. Some environmental contaminants such as vinclozolin, bisphenol A and butyl benzyl phthalate, which 
are usually detected in the waste water, have all been shown to be anti-androgens (Sohoni and Sumpter 1998). Furthermore, the anti-androgenic activities of some phenolic compounds including 4-t-octylphenol, 2,4-dichlorophenol (2,4-DCP) and 4-phenylphenol, also have been reported (Tamura et al. 2006). Once bound to androgen receptor, the androgen antagonists are transported into the nucleus and prevent endogenous androgens from regulating androgen-dependent transcription. The androgen receptorcompound interaction may be crucial contributor to adverse effects on male reproductive system. Exposure of fish to anti-androgens like organochlorine pesticides (OCPs) has been associated with gonadal changes (induction of intersex), reduced spermatogenesis, demasculinization, and reduced sperm counts (Kiparissis et al. 2003).

The potential activity of samples via progesterone receptor was investigated using recombined progesterone receptor yeast, in which none of the above-mentioned waste water extracts showed agonistic activity (Table 2). Antagonist activity was determined by co-incubation with $1 \times 10^{-9} \mathrm{~mol} / \mathrm{L}$ progesterone. In the results, all samples showed strong antagonistic effects with RU486 equivalent concentrations more than $2.3 \times 10^{-6} \mathrm{~g} / \mathrm{L}$ (Table 2). All water samples decreased the $\beta$-galactosidase expression obviously (Fig. 3). It was also found that there was an effective elimination of progesterone receptor antagonists after treatment and the removal efficiencies were more than $90 \%$.

To date, few environmental chemicals have been found to be progesterone receptor agonists or antagonists. The fact that waste water extracts inhibited of progesterone

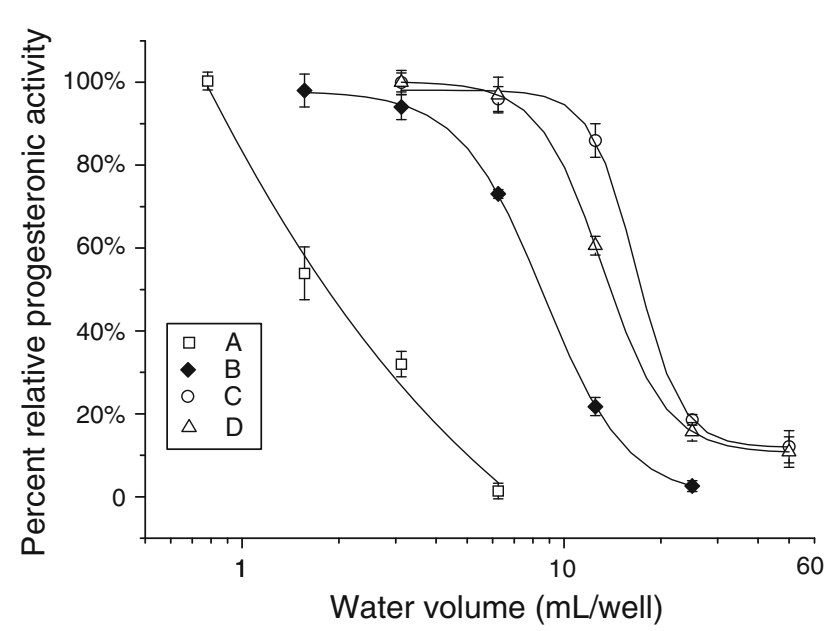

Fig. 3 Progesterone receptor antagonistic activities of water extracts determined by the progesterone receptor yeast bioassay. The samples were collected from Datansha waste water treatment plant and the sample's antagonistic activity is represented as the percent induction activity relative to the maximum induced by progesterone $\left(1 \times 10^{-9}\right.$ $\mathrm{mol} / \mathrm{L})$. Values are presented as the average \pm standard error $(\mathrm{n}=3)$. $A$ extract of influent, $B$ extract of effluent after sand filter treatment, $C$ extract of effluent from train $1, D$ extract of effluent from train2 receptor-controlled $\beta$-galactosidase expression suggests that they contain some progesterone receptor antagonists. The occurrence of in vitro progesterone receptor antagonists in waste water effluents had not been reported previously as far as we are aware. The only previous relative report of anti-progesteronic properties in soot from fossil fuel combustion was reported by Wang et al. (2005), but the responsible compounds did not find. Previous results have demonstrated some OCPs and phenolic compounds, such as DDT, DDE, 4-t-octylphenol and pentachlorophenol, to be antagonists (Tran et al. 1996; Li et al. 2008a). The ability of antagonist to inhibit progesterone-induced gene transcription in the yeast may reflect the ability of antagonist to compete with progesterone for binding to progesterone receptor.

Recent years, several classes of environmental contaminants or their metabolites are found to have the abilities to alter thyroid hormone homeostasis through interference with the thyroid hormone signal transduction pathway (Meerts et al. 2000). We want to know the efficiency of processes to treatment thyroid disrupting chemicals. So, the thyroid receptor agonistic and antagonistic activities of water samples were investigated by using the thyroid receptor yeast with the $\beta$-galactosidase reporter gene. Neither influent nor effluent increased $\beta$-galactosidase expression compared with negative control. However, the influents (sample A) and one effluent (sample B) had thyroid receptor antagonistic activities that inhibited activity of $\beta$-galactosidase expression in a concentration dependent manner (Fig. 4). The amiodarone hydrochloride equivalent concentrations ranged

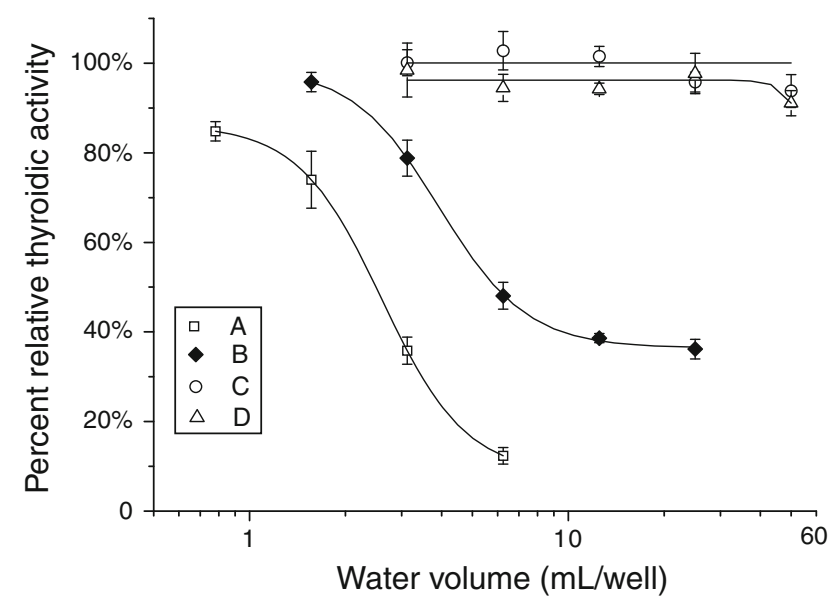

Fig. 4 Thyroid receptor antagonistic activities of water extracts determined by the thyroid receptor yeast bioassay. The samples were collected from Datansha waste water treatment plant and the sample's antagonistic activity is represented as the percent induction activity relative to the maximum induced by 3,3',5-triiodo-L-thyronine (T3, $\left.5 \times 10^{-7} \mathrm{~mol} / \mathrm{L}\right)$. Values are presented as the average \pm standard error $(\mathrm{n}=3)$. $A$ extract of influent, $B$ extract of effluent after sand filter treatment, $C$ extract of effluent from train1, $D$ extract of effluent from train 2 
from $4.6 \times 10^{-5}$ to $1.7 \times 10^{-4} \mathrm{~g} / \mathrm{L}$. In comparison, other effluents (sample C, D) were not detected the inhibiting activities of $\beta$-galactosidase expression, showing that the present processes can effectively move the thyroid receptor antagonists.

Extensive research over the past decade has identified a rapid growing list of environmental contaminants that disrupts thyroid system in many organisms, particularly through interaction directly with thyroid receptor. These chemicals are able to mimic, enhance or antagonize the biological activity of endogenous hormones, $\mathrm{T}_{3}$ and $3,3^{\prime}, 5,5^{\prime}$-tetraiodoL-thyronine $\left(\mathrm{T}_{4}\right)$. Chemicals like 2,4-DCP, 3,4-DCP, 4-toctylphenol and pentachlorophenol have been shown to have thyroid disrupting potentials ( $\mathrm{Li}$ et al. 2008b). Gutleb et al. (2005) reported that sediment extracts showed thyroid inhibition activities in the presence of $\mathrm{T}_{3}$ using $\mathrm{T}$-screen method. In addition, they proposed that these thyroid inhibition activities were partly related to the locations where are heavily polluted with waste water effluent (Gutleb et al. 2005). Our present results supported their hypothesis that there are a large amount of thyroid receptor antagonists in the waste water influent, and suggested that the sediment may be polluted if these antagonists are not efficiently treated and discharged in the effluent.

In conclusion, a battery of in vitro recombinant yeast bioassays was conducted to assess the estrogen receptor, androgen receptor, progesterone receptor and thyroid receptor ant/agonistic potencies of influent and effluents collected from Datansha WWTP. The results demonstrated that estrogenic, anti-androgenic, anti-progesteronic and anti-thyroidic activities were detected in the influents of Datansha WWTP. Assessment of the effluents of WWTP revealed the present wastewater treatment processes were good enough to remove most of these agonists and antagonists, the removal efficiencies were more than $80 \%$.

\section{References}

Boas M, Feldt-Rasmussen U, Skakkebæk NE, Main KM (2006) Environmental chemicals and thyroid function. European $\mathrm{J}$ Endocrinol 154:599-611

Cargouët M, Perdiz D, Mouatassim-Souali A, Tamisier-Karolak S, Levi Y (2004) Assessment of river contamination by estrogenic compounds in Paris area (France). Sci Total Environ 324:55-66

Clara M, Kreuzinger N, Strenn B (2005) The solids retention time: a suitable design parameter to evaluate the capacity of wastewater treatment plants to remove micropollutants. Water Res 39:97106

Colborn T, vom Saal FS, Soto AM (1993) Developmental effects of endocrine-disrupting chemicals in wildlife and humans. Environ Health Perspect 101:378-384

Fawell JK, Sheahan D, James HA, Hurst M, Scott S (2001) Oestrogens and oestrogenic activity in raw and treated water in severn trent water. Water Res 35:1240-1244
Gaido KW, Leonard LS, Lovell S, Gould JC, Babai D, Portier CJ (1997) Evaluation of chemicals with endocrine modulating activity in a yeast-based steroid hormone receptor gene transcription assay. Toxicol Appl Pharmacol 143:205-212

Graham JD, Clarke CL (1997) Physiological action of progesterone in target tissues. Endocr Rev 18:502-519

Gutleb AC, Meerts IATM, Bergsma JH, Schriks M, Murk AJ (2005) T-Screen as a tool to identify thyroid hormone receptor active compounds. Environ Toxicol Pharmacol 19(2):231-238

Janošek J, Hilscherová K, Bláha L, Holoubek I (2006) Environmental xenobiotics and nuclear receptors-Interactions, effects and in vitro assessment. Toxicol In Vitro 20:18-37

Kiparissis Y, Metcalfe TL, Balch GC, Metcalfe CD (2003) Effects of antiandrogens, vinclozolin and cyproterone acetate on gonadal development in the Japanese medaka (Oryzias latipes). Aquat Toxicol 63:391-403

Kristensen T, Baatrup E, Bayley M (2006) p, p'-DDE fails to reduce the competitive reproductive fitness in Nigerian male guppies. Ecotox Environ Safe 63(1):148-157

Li J, Ma M, Giesy JP, Wang ZJ (2008a) In vitro profling of endocrine disrupting potency of organchlorine pesticides. Toxicol Lett 183:65-71

Li J, Ma M, Wang ZJ (2008b) A two-hybrid yeast assay to quantify the effects of xenobiotics on thyroid hormone-mediated gene expression. Environ Toxico Chem 27(1):159-167

Ma M, Li J, Wang Z (2005) Assessing the detoxication efficiencies of wastewater treatment processes using a battery of bioassays/ biomarkers. Arch Environ Contam Toxicol 49:480-487

Meerts IATM, van Zanden JJ, Luijks EAC, van Leeuwen-Bol I, Marsh G, Jacobsson E, Bergman A, Brouwer A (2000) Potent competitive interactions of some brominated flame retardants and related compounds with human transthyretin in vitro. Toxicol Sci 56:5-104

Peng X, Yi Yu, Tang C, Tan HuangQ, Wang Z (2008) Occurrence of steroid estrogens, endocrine-disrupting phenols, and acid pharmaceutical residues in urban riverine water of the Pearl River Delta, South China. Sci Total Environ 397:158-166

Routledge EJ, Sumpter JP (1996) Estrogenic activity of surfactants and some of their degradation products assessed using a recombinant yeast screen. Environ Toxicol Chem 15:241-248

Sohoni P, Sumpter JP (1998) Several environmental oestrogens are also anti-androgens. J Endocrinol 158:327-339

Sonnenschein C, Soto AM (1998) An updated review of environmental estrogen and androgen mimics and antagonists. J Steroid Biochem Mol Biol 65:143-150

Sun Q, Deng S, Huang J, Shen G, Yu G (2008) Contributors to estrogenic activity in wastewater from a large wastewater treatment plant in Beijing, China. Environ Toxicol Pharmacol 25:20-26

Svenson A, Allard AS, Ek M (2003) Removal of estrogenicity in Swedish municipal sewage treatment plants. Water Res 37:4433-4443

Tabata A, Kashiwada S, Ohnishi Y, Ishikawa H, Miyamoto N, Itoh M, Magara Y (2001) Estrogenic influences of estradiol-17 $\beta$, $p$ nonylphenol and bis-phenol-A on Japanese Medaka (Oryzias latipes) at detected environmental concentrations. Water Sci Technol 43:109-116

Tamura H, Ishimoto Y, Fujikawa T, Aoyama H, Yoshikawa H, Akamatsu M (2006) Structural basis for androgen receptor agonists and antagonists: Interaction of SPEED 98-listed chemicals and related compounds with the androgen receptor based on an in vitro reporter gene assay and 3D-QSAR. Bioorgan Med Chem 14:7160-7174

Tollefsen KE, Harman C, Smith A, Thomas KV (2007) Estrogen receptor (ER) agonists and androgen receptor (AR) antagonists 
in effluents from Norwegian North Sea oil production platforms. Mar Pollut Bull 54(3):277-283

Tran DQ, Klotz DM, Ladile BL (1996) Inhibition of progesterone receptor activity in yeast by synthetic chemicals. Biochem Bioph Res Co 229:518-523

Wang J, Xie P, Kettrup A, Schramm KW (2005) Inhibition of progesterone receptor activity in recombinant yeast by soot from fossil fuel combustion emissions and air particulate materials. Sci Total Environ 349:120-128
Wu WZ, Wang JX, Zhao GF, You L (2002) The emission soot of biomass fuels combustion as a source of endocrine disrupters. J Environ Sci Health A 37:579-600

Xu LC, Sun H, Chen JF, Bian Q, Qian J, Song L, Wang XR (2005) Evaluation of androgen receptor transcriptional activities of bisphenol A, octylphenol and nonylphenol in vitro. Toxicology 216:197-203 